УДК 378.093:793.3(477.411)КДІК

DOI: 10.31866/2616-7646.4.2.2021.249281

\title{
СТАНОВЛЕННЯ МИСТЕЦЬКО-ПЕДАГОГІЧНОЇ ШКОЛИ КАФЕДРИ ХОРЕОГРАФІЇ КИЇВСЬКОГО ІНСТИТУТУ КУЛЬТУРИ ІМЕНІ О. Є. КОРНІЙЧУКА
}

\author{
Миронюк Наталія Миколаївна, \\ викладач, \\ Київський національний університет культури і мистецтв, \\ Київ, Україна, \\ https://orcid.org/0000-0001-7413-7112, \\ sorbedukr.net
}

\begin{abstract}
Мета статті - проаналізувати процес становлення мистецько-педагогічної школи кафедри хореографії КДІК ім. О. Є. Корнійчука. Методологія. Систематизація інформації, розгляд подій у хронологічній послідовності, екстраполяція змісту поняття «наукова школа» в художньо-педагогічну галузь дозволили здійснити науково об'єктивне дослідження. Наукова новизна. Вперше проаналізовано створення кафедри хореографії Київського державного інституту культури імені О. Є. Корнійчука в аспекті становлення художньо-педагогічної школи. Висновки. Створення першої в УРСР кафедри хореографії у Київському державному інституті культури імені О. Є. Корнійчука стало одночасно фундаментом для мистецько-педагогічної школи, лідер якої К. Василенко об’єднав однодумців, що дотримувалися прогресивних принципів єдиної творчої команди, здатної до критики та самокритики, паритетних стосунків керівника-лідера та членів команди. Серед першого складу кафедри, що стояв біля витоків мистецько-педагогічної школи, - А. Гуменюк, Г. Березова, В. Володько, В. Пасютинська, Ф. Баклан та ін. Специфіка такої школи полягає в синтезуванні педагогічної, мистецької та наукової діяльності. Постановочна творчість педагогів та студентів, виконавська діяльність студентів в інституті та поза ним, участь у різних мистецьких заходах дозволяє розглядати діяльність кафедри хореографії не лише як навчально-тренувальну практику, а як внесок у розвиток хореографічного мистецтва. Основним напрямом діяльності мистецько-педагогічної школи було обрано розвиток народно-сценічної хореографії, формування методичних основ українського танцю як самостійної навчальної дисципліни, що привело до збагачення репертуару студентського колективу на кафедрі українськими народно-сценічними танцями та поширення цієї тенденції у практичній діяльності випускників. Цей аспект творчого розвитку кафедри є доволі перспективним для подальших наукових розвідок.
\end{abstract}

Ключові слова: кафедра хореографії Київського інституту культури; мистецько-педагогічна школа; Кім Василенко; хореографія; танець. 


\section{СТАНОВЛЕНИЕ ХУДОЖЕСТВЕННО- ПЕДАГОГИЧЕСКОЙ ШКОЛЫ КАФЕДРЫ ХОРЕОГРАФИИ КИЕВСКОГО ИНСТИТУТА КУЛЬТУРЫ ИМЕНИ О. Е. КОРНИЙЧУКА}

\author{
Миронюк Наталья Николаевна, \\ преподаватель, \\ Киевский национальный университет \\ культуры и искусств, \\ Киев, Украина, \\ https://orcid.org/0000-0001-7413-7112, \\ sorbedukr.net
}

Цель статьи - проанализировать процесс становления художественно-педагогической школы кафедры хореографии КГИК им. Е. Е. Корнейчука. Методология. Систематизация информации, рассмотрение событий в хронологической последовательности, экстраполяция содержания понятия «научная школа» в художественно-педагогическую область позволили осуществить научно объективное исследование. Научная новизна. Впервые проанализировано создание кафедры хореографии Киевского государственного института культуры имени Корнейчука в аспекте становления художественно-педагогической школы. Выводы. Создание первой в УССР кафедры хореографии в Киевском государственном институте культуры имени А. Е. Корнийчука стало одновременно фундаментом для художественно-педагогической школы, лидер которой К. Василенко объединил единомышленников, придерживавшихся прогрессивных принципов единой творческой команды, способной к критике и самокритике. паритетных отношений руководителя-лидера и членов команды Среди первого состава кафедры, стоявшего у истоков художественно-педагогической школы, А. Гуменюк, Г. Березова, В. Володько, В. Пасютинская, Ф. Баклан и т.д. Специфика такой школы заключается в синтезе педагогической, художественной и научной деятельности. Постановочное творчество
FORMATION OF THE ARTISTIC AND PEDAGOGICAL SCHOOL OF THE CHOREOGRAPHY DEPARTMENT AT THE KYIV INSTITUTE OF CULTURE NAMED AFTER 0. Ye. KORNIICHUK

\author{
Nataliia Myroniuk, \\ Lecturer, \\ Kyiv National University \\ of Culture and Arts, \\ Kyiv, Ukraine, \\ https://orcid.org/0000-0001-7413-7112, \\ sorbedukr.net
}

The purpose of the article is to analyze the process of the artistic and pedagogical school formation of the choreography department of KSIC named after O. Ye. Korniichuk. Research methodology. Systematization of information, consideration of events in chronological order, extrapolation of the content of the concept of 'scientific school' in the artistic and pedagogical field allowed to carry out scientifically objective research. Scientific novelty. For the first time, the creation of the choreography department at the Kyiv State Institute of Culture named after O. Ye. Korniichuk in the aspect of formation of art and pedagogical school is analyzed. Conclusions. The creation of the first choreography department in the USSR at the Kyiv State Institute of Culture named after O.Ye. Korniychuk became the foundation for the art and pedagogical school, the leader of which K. Vasylenko united like-minded people who adhered to the progressive principles of a single creative team capable of criticism and self-criticism, parity relations between the leader and team members. Among the first members of the department who stood at the origins of the art and pedagogical school - A. Humeniuk, H. Berezova, V. Volodko, V. Pasiutynska, F. Baklan and others. The specificity of such a school is the synthesis of pedagogical, artistic and scientific activities. Staging creativity of teachers and students, performing activities of students inside and outside the institute, par- 
педагогов и студентов, исполнительская деятельность студентов в институте и вне его, участие в различных художественных мероприятиях позволяет рассматривать деятельность кафедры хореографии не только как учебно-тренировочную практику, а как вклад в развитие хореографического искусства. Основным направлением деятельности художественно-педагогической школы было избрано развитие народно-сценической хореографии, формирование методических основ украинского танца как самостоятельной учебной дисциплины, что привело к обогащению репертуара студенческого коллектива на кафедре украинскими народно-сценическими танцами и распространению этой тенденции в практической деятельности выпускников. Этот аспект творческого развития кафедры достаточно перспективен для дальнейших научных исследований.

Ключевые слова: кафедра хореографии Киевского института культуры; художественно-педагогическая школа; Ким Василенко; хореография; танец. ticipation in various artistic events allows us to consider the activities of the Department of Choreography not only as a training practice, but as a contribution to choreographic art. The main activity of the art and pedagogical school was the development of folk stage choreography, the formation of the methodological foundations of Ukrainian dance as an independent educational discipline, which led to the enrichment of the repertoire of the student team at the department of Ukrainian people's stage dances and the spread of this trend in the practical activities of graduates. This aspect of the creative development of the department is quite promising for further scientific research.

Keywords: Choreography Department of Kyiv Institute of Culture; art and pedagogical school; Kim Vasylenko; choreography; dance

Актуальність теми дослідження. Українська хореографічна культура в 1970-1980-х рр. отримала потужний імпульс завдяки становленню вищої хореографічної освіти, зокрема, створенню кафедри хореографії Київського державного інституту культури (далі - КДІК) ім. О. Є. Корнійчука. Слід зазначити, що діяльність кафедри не можна розглядати лише в навчально-виховному аспекті, оскільки її мистецькі досягнення виходить далеко за межі вищого навчального закладу. Зважаючи на це, доцільно розглянути створення кафедри в оптиці заснування мистецько-педагогічної школи.

Аналіз останніх досліджень та публікацій. Попри значущість ролі кафедри хореографії КДІК ім. О. Є. Корнійчука в розвитку української хореографічної культури її діяльність не стала предметом спеціального наукового дослідження. Окремі аспекти означеного питання частково розглянули О. Благова (2021), О. Жиров (2007), Т. Луговенко (2018) та ін. Безпосередньо різним напрямам роботи кафедри присвячено наукові публікації І. Гутник (2019), А. Підлипської (2015), Л. Цвєткової (2020) та ін. Проте в жодному із джерел створення кафедри хореографії КДІК ім. О. Є. Корнійчука не розглядалося як початок діяльності мистецько-педагогічної школи.

Мета статті - проаналізувати процес становлення мистецько-педагогічної школи кафедри хореографії КДІК ім. О. Є. Корнійчука.

Виклад основного матеріалу. Розгляд становлення та функціонування мистецько-педагогічної школи кафедри хореографії в період від її відкриття (1970р.) 
до здобуття Україною незалежності 1991 р. не заперечує принципів послідовності та спадковості, продовження певних векторів розвитку в подальшому. Наступний етап (від 1991 р. до сьогодення) необхідно досліджувати окремо, зважаючи на інший соціокультурний контекст, низку трансформаційних процесів як в освітній, так і в культурно-мистецькій сферах. У рамках дослідження першого етапу «життєдіяльності» кафедри 1970-1971 pр., який можна вважати періодом формування та стабілізації організаційних, методичних та художніх принципів роботи, важливим видається створення цього структурного підрозділу, що означав початок формування мистецько-педагогічної школи кафедри хореографії КДІК ім. О. Є. Корнійчука.

Для такого дослідження необхідно враховувати закономірності розвитку соціокультурної, мистецької в цілому та безпосередньо хореографічної сфер, зокрема, домінування певних тенденцій розвитку хореографічного мистецтва на різних етапах діяльності кафедри.

Специфіка випускаючих кафедр мистецьких спеціальностей полягає в поєднанні не лише навчальної, а й художньої діяльності, що є обов’язковим складником функціонування таких осередків. Виконавська та постановочна творчість закладі освіти та за його межами засвідчує правомірність їі розгляду не лише як навчально-тренувальної діяльності, а й як повноцінного внеску в розвиток хореографічного мистецтва.

Попри те, що до кафедри в навчальному закладі не слід ставитись як до професійного чи аматорського концертуючого колективу, без практичної сценічної діяльності неможливе формування високопрофесійних фахівців-хореографів 3 виконавської, балетмейстерської, адміністративно-управлінської діяльності. Отже, концерні виступи на майданчиках різного рівня (від демонстрації свого доробку в танцювальному класі під час відкритих показів на заліках та іспитах, відкритих уроків, різноаспектних заходів закладу до сценічних виступів на майданчиках України та світу в рамках фестивалів, конкурсів, різноманітних концертів та інших заходів) є свідченням продуктивної мистецької творчості, відповідно, демонстрацією результатів роботи певної мистецько-педагогічної школи.

Беручи за основу положення щодо наукової школи, сформульовані В. Шейком, М. Каністратенком та Н. Кушнаренко (2011, с. 6), А. Підлипська (2013) подає визначення мистецької школи як «... неформальне і/або формальне творче об’єднання декількох поколінь митців, характерними ознаками якого $є$ наявність митця-лідера засновника творчого напряму (програми), його учнів-послідовників, прибічників сталих традицій, сформованих у творчому колективі, згуртованість навколо успішного розв'язання соціально і професійно значущої творчої проблеми, ефективність функціонування школи, свідченням чого є якість та кількість мистецьких проєктів та навчально-тренувальної діяльності, підготовлених митців, прилюдних виступів тощо» (с. 345-346). Це визначення стосується як суто мистецьких угруповань у хореографічній культурі, так і неформальних об'єднань педагогів-митців, коли відбувається перехід таких осередків на якісно новий рівень.

Тяглість виконавських, балетмейстерських, педагогічних методів є однією з важливих умов розвитку хореографічного мистецтва, специфіка якого полягає в передаванні «3 рук у руки» («3 ніг у ноги») в усний спосіб секретів професії. Такі процеси відбуваються в межах не просто об'єднань митців, а своєрідних мистець- 
ко-педагогічних шкіл, які можуть бути як неформальними, так і інституалізованими осередками.

Термін «мистецько-педагогічна школа» не такий поширений, як «наукова школа». Постає проблема виявлення ознак мистецько-педагогічної школи, що дало б змогу відокремити її від інших форм взаємодії і в мистецькій діяльності, і в педагогічній творчості. Йдеться про митців, які провадять педагогічну діяльність, передають свої знання, сприяють формуванню вмінь і навичок у своїх учнів.

Вважаємо, що вживання терміна «мистецько-педагогічна школа» $€$ цілком виправданим стосовно діяльності кафедри хореографії Київського інституту культури імені О. Є. Корнійчука у 1970-1991рр. Кафедру було створено за ініціативи відомого діяча танцювального мистецтва, балетмейстера самодіяльних колективів народного танцю, теоретика українського народного танцю, авторитетного фахівця Кіма Юхимовича Василенка. К. Василенко упродовж багатьох років (на посаді завідувача кафедри та в подальшій викладацькій роботі) був лідером серед колег та наставником для молодих фахівців. Для організації роботи кафедри К. Василенко запросив знану артистку балету, балетмейстера, педагога, ученицю А. Ваганової, заслужену артистку України Галину Олексіївну Березову. Вона вже мала досвід викладання в Київському державному хореографічному училищі, керівником та педагогом якого була впродовж багатьох років. К. Василенко розумів важливість академічних основ для підготовки майбутніх керівників самодіяльних хореографічних колективів (саме таку кваліфікацію отримували випускники кафедри у 1970-х - 1980-х рр.). Класичний танець як універсальна система виховання танцівника, формування виконавської та балетмейстерської культури хореографів став однією з основних дисциплін на кафедрі.

Також одним із перших для роботи на кафедрі було запрошено фольклориста, музиканта, збирача танцювального та музичного фольклору, автора дослідження «Народне хореографічне мистецтво України» (Гуменюк, 1963), а також укладача збірника «Українські народні танці» (Гуменюк \& Вірський, 1969), значну частину зразків в якому було записано під час польових досліджень саме укладачем, доктора мистецтвознавства, професора Андрія Івановича Гуменюка. Музично-фольклористичний вектор підготовки фахівців на кафедрі свідчить про тогочасні пріоритети розвитку народного, точніше, народно-сценічного танцю, становлення методики викладання українського народного танцю в рамках самостійної дисципліни.

Взаємодія потужних професіоналів стала запорукою підготовки висококваліфікованих фахівців хореографічного мистецтва. Саме тоді було закладено основи мистецько-педагогічної школи кафедри хореографії (з 1994 року - кафедри народної хореографії) КДІК імені О. Є. Корнійчука.

Кафедра першою в УРСР розпочала підготовку фахівців хореографічного мистецтва з вищою освітою. І не безпідставно цю заслугу О. Жиров (2007) приписує К. Василенку, кваліфікуючи в періодизації його творчості час між 1970 та 1978 рр. як «започаткування системи вищої хореографічної освіти в Україні» (с. 182), адже завдяки організаційно-управлінським здібностям К. Василенка вдалося не лише відкрити, а й потужно розвинути цей осередок народно-сценічного танцю. Отже, керівник створеної кафедри був лідером в колі однодумців, фактично, фундатором мистецько-педагогічної школи. 
Перед засновниками кафедри постали складні проблеми залучення до викладацької роботи професіоналів, розроблення навчальних планів та програм підготовки фахівців хореографічного мистецтва, потреба в яких в Україні була надзвичайно гострою.

За спогадами Л. Цвєткової (2020), яка потрапила до першого набору студентів на кафедру (згодом - відомого педагога класичного танцю, завідувача кафедри народної хореографії та декана режисерсько-хореографічного та хореографічного факультетів), окрім К. Василенка, завідувача кафедри, який викладав «Мистецтво балетмейстера» і Г. Березової - майстерного викладача класичного танцю, до педагогічного складу було залучено багато професіоналів. «Народно-сценічний танець ми опановували під керівництвом блискучої характерної танцюристки, солістки Державного академічного театру опери та балету (далі - ДАТОБ) ім. Т. Шевченка - Ванди Федорівни Володько. Курси «Історико-побутовий танець» та «Історія хореографічного мистецтва» були доручені кандидату мистецтвознавства - Валерії Матвіївні Пасютинській, автору посібника "Волшебный мир танца” (Москва, 1985) та ін. Перші кроки у формуванні українського танцю як навчальної дисципліни здійснював артист балету ДАТОБ ім. Т. Шевченка - Федір Михайлович Баклан», - згадує Л. Цвєткова (2020, с. 14).

Важливою рисою для успішного функціонування мистецько-педагогічної школи є певний стиль роботи, своєрідний «клімат», що створюється спільними зусиллями лідера та однодумців, які попри розбіжність індивідуальних поглядів, ідей та стилів викладацької та мистецької діяльності об’єднуються й генерують атмосферу піднесення в процесі вирішення актуальних завдань.

Дослідник проблем наукових шкіл С. Гончаренко (2013) вважає показовим для таких осередків «... визнання вирішальною цінністю не службового положення наукового керівника, а силу й своєрідність його мислення; дух партнерства в пошуках розв'язання проблеми, в пошуках істини; сміливої ініціативи; повага до критики, виховання здатності до самокритики» (с. 9). Вважаємо можливим екстраполяцію умовиводів знаного науковця в площину мистецько-педагогічних шкіл. Саме така ситуація авторитетності, а не авторитарності завідувача кафедри хореографії К. Василенка склалася в КДІК ім. О. Є. Корнійчука; саме партнерські стосунки стали запорукою успішного налагодження системи підготовки професійних керівників аматорських хореографічних колективів, а також виконавців та балетмейстерів у вищому навчальному закладі. I це неможливо було реалізувати без ініціативності кожного, хто увійшов до педагогічного складу, без здатності поглянути на власні дії зі сторони та критично поставитися до власної методики, без належного ставлення до критики колег. Слід зазначити, що вже з перших років існування кафедри було закладено принципи методичних семінарів, обговорень відкритих занять, концертних виступів студентів з метою удосконалення методики викладання та досягнення високих художніх результатів у сценічній творчості.

На думку багатьох дослідників, учні, послідовники в подальшому не обов'язково повинні розвивати виключно ідеї вчителя. Перспективність та творчий потенціал тієї чи іншої мистецько-педагогічної школи залежить від здатності активно генерувати нові творчі ідеї та провадити підготовку власних учнів, базуючись на міцній школі, переглядаючи та оновлюючи її методи та принципи. Таке 
постійне прагнення до вдосконалення властиве вже першому педагогічному та студентському складу кафедри.

На думку С. Гончаренка (2013), для успішного функціонування «школи» обов’язковими є такі умови, як прогресивність та перспективне бачення напрямів діяльності, за якими майбутне. І ці умови вже з перших років існування виконувалися на кафедрі хореографії, де завідувач не гальмував розвиток колег, сприяв упровадженню нових дисциплін, які до того не викладалися в жодному хореографічному навчальному закладі (наприклад, український народний танець), постійно прагнув залучити до викладання не лише сформованих за межами інституту професіоналів, а й перспективних вихованців кафедри.

Слід зауважити, що назва «мистецько-педагогічна школа» не означає відсутність науково-дослідницької роботи на кафедрі, свідченням чому стали численні наукові та навчально-методичні праці викладачів, а згодом - і вихованців кафедри.

Наукова новизна. Вперше проаналізовано створення кафедри хореографії Київського державного інституту культури імені О. Є. Корнійчука в аспекті становлення художньо-педагогічної школи.

Висновки. Створення першої в УРСР кафедри хореографії в Київському державному інституті культури імені О. Є. Корнійчука стало одночасно фундаментом для мистецько-педагогічної школи, лідер якої К. Василенко об'єднав однодумців, що дотримувалися прогресивних принципів єдиної творчої команди, здатної до критики та самокритики, паритетних стосунків керівника-лідера та членів команди. Серед складу кафедри, що стояв біля витоків мистецько-педагогічної школи, - А. Гуменюк, Г. Березова, В. Володько, В. Пасютинська, Ф. Баклан та ін.

Специфіка такої школи полягає в синтезуванні педагогічної, мистецької та наукової діяльності. Постановочна творчість педагогів та студентів, виконавська діяльність студентів в інституті та поза ним, участь у різних мистецьких заходах дозволяє розглядати діяльність кафедри хореографії не лише як навчально-тренувальну практику, а як внесок у розвиток хореографічного мистецтва.

Основним напрямом діяльності мистецько-педагогічної школи було обрано розвиток народно-сценічної хореографії, формування методичних основ українського танцю як самостійної навчальної дисципліни, що привело до збагачення репертуару студентського колективу на кафедрі українськими народно-сценічними танцями та поширення цієї тенденції в практичній діяльності випускників. Цей аспект творчого розвитку кафедри $є$ доволі перспективним для подальших наукових розвідок.

\section{СПИСОК ПОСИЛАНЬ}

Благова, Т. О. (2021). Розвиток хореографічної освіти в Україні (XX - початок XXI століття) [Дисертація доктора педагогічних наук, Полтавський національний педагогічний університет імені В. Г. Короленка].

Гончаренко, С. (2013). Наукові школи в педагогіці. Освіта дорослих: теорія, досвід, перспективи, 6, 7-28.

Гуменюк, А. І. (1963). Народне хореографічне мистецтво України. Видавництво АН УРСР.

Гуменюк, А. І. (Уклад.), \& Вірський, П. П. (Ред). (1969). Українські народні танці. Наукова думка. 
Гутник, І. (2019). Кафедра народної хореографії Київського національного університету культури і мистецтв в контексті становлення та розвитку вищої хореографічної освіти в Україні. Вісник Національної академії керівних кадрів культури і мистецтв, 3 , 251-257. https://doi.org/10.32461/2226-3209.3.2019.191775

Жиров, О. (2007). Розвиток української народної хореографії у мистецько-педагогічній спадщині та діяльності К. Василенка (50-90 роки XX cm.) [Дисертація кандидата педагогічних наук, Житомирський державний університет імені Івана Франка].

Луговенко, Т. Г. (2018). Роль взаємозв’язку професійних та самодіяльних колективів народного танцю у вихованні підростаючого покоління в Україні (40-80-і роки XX століття). Науковий часопис Національного педагогічного університету імені М. П. Драгоманова. Серія 5. Педагогічні науки: реалії та перспективи, 63, 102-107.

Підлипська, А. М. (2013). Регіональні школи бального танцю в Україні. Актуальні проблеми історії, теорії та практики художньої культури, 30, 344-350.

Підлипська, А. М. (2015, 17-18 квітня). Кафедра хореографії Київського державного інституту культури ім. О. Є. Корнійчука крізь призму соціокультурної політики другої половини XX століття. В А. М. Підлипська (Упоряд.), Динаміка розвитку вищої хореографічної освіти як складової художньої культури України (до 45-річчя заснування кафедри хореографії КНУКіМ), Матеріали Всеукраїнської науково-практичної конференції, м. Київ (с. 31-36). Видавничий центр КНУКіМ.

Цвєткова, Л. Ю. (2020, 25 квітня). «Вдячність крізь десятиліття» (педагоги-фундатори кафедри хореографії Київського державного інституту культури). В А. М. Підлипська (Упоряд.), Традиції та новації в хореографічній культурі (до 50-річчя кафедри хореографії Київського національного університету культури і мистецтвв), Матеріали Міжнародної науково-практичної конференції, м. Київ (с. 12-17). Видавничий центр КНУКіМ.

Шейко, В. М., Каністратенко, М. М., \& Кушнаренко, Н. М. (2011). Наукові школи культурологічно-мистецького та бібліотечно-інформаційного профілів: ознаки ідентифікації. Вісник Харківської державної академії культури, 34, 4-18.

\section{REFERENCES}

Blahova, T. (2021). Rozvytok Khoreohrafichnoi Osvity v Ukraini (XX - Pochatok XXI Stolittia) [Development of Choreographic Education in Ukraine (XX - Early XXI Century)] [Doctoral Dissertation, Poltava V. G. Korolenko National Pedagogical University] [in Ukrainian].

Gutnyk, I. (2019). Kafedra Narodnoi Khoreohrafii Kyivskoho Natsionalnoho Universytetu Kultury i Mystetstv v Konteksti Stanovlennia ta Rozvytku Vyshchoi Khoreohrafichnoi Osvity v Ukraini [Departament of Folk Choreography of the Kyiv National University of Culture and Arts in the Context of Establishment and Development of Higher Choreographic Education in Ukraine]. Visnyk Natsionalnoi Akademii Kerivnykh Kadriv Kultury i Mystetstv [National Academy of Managerial Staff of Culture and Arts Herald], 3, 251-257. https://doi. org/10.32461/2226-3209.3.2019.191775 [in Ukrainian].

Honcharenko, S. (2013). Naukovi Shkoly v Pedahohitsi [The Problem of Scientific Schools in Pedagogy]. Osvita Doroslykh: Teoriia, Dosvid, Perspektyvy [Adult Education: Theory, Experience, Prospects], 6, 7-28 [in Ukrainian].

Humeniuk, A. (1963). Narodne Khoreohrafichne Mystetstvo Ukrainy [Folk Choreographic Art of Ukraine]. Academy of Sciences of the Ukrainian SSR.

Humeniuk, A. (Comp.), \& Virsky, P. (Ed). (1969). Ukrainski Narodni Tantsi [Ukrainian Folk Dances]. Naukova dumka [in Ukrainian].

Lugovenko, T. (2018). Rol Vzaiemozviazku Profesiinykh ta Samodiialnykh Kolektyviv Narodnoho Tantsiu u Vykhovanni Pidrostaiuchoho Pokolinnia v Ukraini (40-80-i Roky XX Stolittia) 
[The Role of the Relationship between Professional and Amateur Folk Dance Groups in the Education of The Younger Generation in Ukraine (40-80s of the Twentieth Century)]. Naukovyi Chasopys Natsionalnoho Pedahohichnoho Universytetu imeni M. Drahomanova. Seriia 5. Pedahohichni Nauky: Realii ta Perspektyvy, 63, 102-107 [in Ukrainian].

Pidlypska, A. (2013). Rehionalni Shkoly Balnoho Tantsiu v Ukraini [Regional Ballroom Dance Schools in Ukraine]. Aktualni Problemy Istorii, Teorii ta Praktyky Khudozhnoi Kultury [Topical Problems of History, Theory and Practice of Artistic Culture], 30, 344-350 [in Ukrainian].

Pidlypska, A. (2015, April 17-18). Kafedra Khoreohrafii Kyivskoho Derzhavnoho Instytutu Kultury im. O. Korniichuka Kriz Pryzmu Sotsiokulturnoi Polityky Druhoi Polovyny XX Stolittia [Department of Choreography of Kyiv State Institute of Culture Through the Prism of Socio-Cultural Policy of the Second Half of the Twentieth Century]. In A. Pidlypska (Comp.), Dynamika Rozvytku Vyshchoi Khoreohrafichnoi Osvity yak Skladovoi Khudozhnoi Kultury Ukrainy (do 45-richchia Zasnuvannia Kafedry Khoreohrafii KNUKiM) [Dynamics of Development of Higher Choreographic Education as a Component of Artistic Culture of Ukraine (to the 45th Anniversary of the Founding of the Department of Choreography KNUKiM)], Proceedings of the All-Ukrainian Scientific and Practical Conference, Kyiv (pp. 31-36). KNUKIM Publishing [in Ukrainian].

Sheiko, V., Kanistratenko, M., \& Kushnarenko, N. (2011). Naukovi Shkoly KulturolohichnoMystetskoho ta Bibliotechno-Informatsiinoho Profiliv: Oznaky Identyfikatsii [Scientific Schools of Culturological-Artistic and Library-Informational Profiles: Signs of Identification]. Visnyk Kharkivskoi Derzhavnoi Akademii Kultury [Visnyk of Kharkiv State Academy of Culture], 34, 4-18 [in Ukrainian].

Tsvietkova, L. (2020, April 25). "Vdiachnist Kriz Desiatylittia" (Pedahohy-Fundatory Kafedry Khoreohrafii Kyivskoho Derzhavnoho Instytutu Kultury) ["Gratitude Through the Decades" (Teachers-Founders of the Department of Choreography of the Kyiv State Institute of Culture)]. In A. Pidlypska (Comp.), Tradytsii ta Novatsii v Khoreohrafichnii Kulturi (do 50-richchia Kafedry Khoreohrafii Kyivskoho Natsionalnoho Universytetu Kultury i Mystetstv) [Traditions and Innovations in Choreographic Culture (to the 50th Anniversary of the Department of Choreography of Kyiv National University of Culture and Arts)], Proceedings of the International Scientific and Practical Conference, Kyiv (pp. 12-17). KNUKIM Publishing [in Ukrainian].

Zhyrov, O. (2007). Rozvytok Ukrainskoi Narodnoi Khoreohrafii u Mystetsko-Pedahohichnii Spadshchyni ta Diialnosti K. Vasylenka (50-90 roky XX st.) [Development of Ukrainian Folk Choreography in the Artistic and Pedagogical Heritage and Activity of K. Vasylenko (50-90s of the XX Century)] [PhD Dissertation, Zhytomyr Ivan Franko State University] [in Ukrainian]. 